\title{
Lack of estrogen receptors expression in malignant and pre-malignant colorectal lesions in Egyptian patients
}

\author{
Mohamed Said $^{1}$, Marwa Khairy ${ }^{1}$, Aly El-Hendawy ${ }^{2}$, Osama A. Khalf ${ }^{3}$, Mohamed S. Abdelbary ${ }^{1}$, \\ Yasmin Saad ${ }^{1}$, Ayman Yosry ${ }^{1}$ \\ ${ }^{1}$ Departement of Endemic Medicine and Hepatogastroenterology, Faculty of Medicine, Cairo University, Cairo, Egypt \\ ${ }^{2}$ Department of Pathology, Faculty of Medicine, Cairo University, Cairo, Egypt \\ ${ }^{3}$ Department of Clinical Pathology, Faculty of Medicine, Cairo University, Cairo, Egypt \\ Email: msabdelaziz76@yahoo.com
}

Received 23 January 2013; revised 20 March 2013; accepted 28 April 2013

Copyright (C) 2013 Mohamed Said et al. This is an open access article distributed under the Creative Commons Attribution License, which permits unrestricted use, distribution, and reproduction in any medium, provided the original work is properly cited.

\section{ABSTRACT}

Background: incidence of Colorectal cancer (CRC) is increasing globally. In Egypt, CRC ranks the sixth most common cancer in males and the fifth in females. Aim: To assess the expression of estrogen receptors (alpha and beta) in pre-malignant (adenomatous polyps and IBD), malignant colorectal lesions and normal colonic mucosa in group of Egyptian patients. Methods: This prospective study was done on 45 patients presenting with colonic symptoms, patients were divided into four groups; 15 CRC patients, 10 patients with adenomatous polyps, 10 IBD patients and 10 patients in the control group. Patients subjected to: Stool analysis, FOBT, CBC, CEA, Abdominal ultrasound \& colonoscopy and biopsy (number = 80), Pathological, immunohistochemistry and RTPCR quantification of ER $\alpha$ and ER $\beta$ were done. Results: Mean age: 39.2 (12 - 73), gender: M/F: 28/17. Bleeding per rectum was the commonest presentation; 29/45 (64.4\%). CEA was significantly elevated in the CRC group compared with other studied groups (1692 $\mathrm{mg} / \mathrm{L}$ vs. $4.0,4.0$ and $4.4 \mathrm{mg} / \mathrm{L}$ ). Ultrasonography of the studied patients showed that metastatic CRC: 3/15 (20\%); Colonic wall thickening: 5/15 (33.3\%), $1 / 10$ showed colonic polypoidal lesions in adenomatous polyps groups, in IBD group: $4 / 10(40 \%)$ showed colonic and ileocecal thicknening. All the studied patients showed negative results for estrogen receptors (alpha and beta) by the use of immunohistochemistry staining and RT-PCR technique. Conclusion: Role of estrogen receptors in the colonic mucosa, precancerous and colorectal cancer is doubtful, contradictory results with some literature data could be due to racial and genetic difference in the studied population.
Keywords: Colorectal Cancer; Premalignant Lesions; Estrogen Receptors

\section{INTRODUCTION}

The incidence of colorectal cancer (CRC) is increasing globally [1], it is ranked as the 4 th most common cancer in males and the 2nd for females [2]. It accounts for more than 655,000 deaths worldwide per year and it accounts for the third leading cause of cancer-related death in the Western world [3]. In Egypt, CRC ranks the sixth most common cancer in males and the fifth in females. CRC was responsible for $3.9 \%$ of all cancer related mortality and ranking in the seventh cause of cancer death [4].

Epidemiological, clinical and experimental evidence reported that E2 confers protection against colon cell proliferation and malignant transformation, reducing the incidence of colon adenoma and carcinoma by about $20 \%$, estrogen receptors (ER) exist in 2 main forms: ER $\alpha$ and $\operatorname{ER} \beta[5] . \mathrm{ER} \beta$ is the dominant ER isoform in normal colonic mucosa playing a key role in the mitogenic action of estrogens by providing protection against ER $\alpha$ induced hyper proliferation and the stimulation of apoptosis [6]. Estrogen receptors (ERs) act by regulating transcriptional processes. The classical mechanism of ER action involves estrogen binding to receptors in the nucleus, after which the receptors dimerize and bind to specific response elements known as estrogen response elements (EREs) located in the promoters of target genes [7]. However, ERs can also regulate gene expression without directly binding to DNA. This occurs through protein-protein interactions with other DNA-binding transcription factors in the nucleus. In addition, membraneassociated ERs mediate nongenomic actions of estrogens, 
which can lead both to altered functions of proteins in the cytoplasm and to regulation of gene expression. The latter two mechanisms of ER action enable a broader range of genes to be regulated than the range that can be regulated by the classical mechanism of ER action alone [8].

$\mathrm{ER} \alpha$ is reported to be minimally expressed in colon cancer cells [9]. ER $\beta$ expression was significantly lower in colon cancer cells than in normal colonic epithelium, which paralleled the loss of malignant colon cell dedifferentiation [10]. Clinical data on the association between IBD and estrogen are conflicting. Estrogen has an impact on the immune system as anti-inflammatory effects [11]. $E R \beta$-selective ligands have been proposed to be therapeutically effective in the treatment of IBD and/or arthritis [12]. ER $\alpha$-selective compounds have not been tested for its effects in IBD patients [13]. Few studies have been conducted, and with conflicting results, on the possible protective effect of estrogens against the development of adenomatous polyps in the colon [14]. Adenomatous polyps are associated with significant reduction of ER $\beta$ expression [15].

This study is designed to assess the expression of estrogen receptors (alpha and beta) in pre-malignant (adenomatous polyps and IBD), malignant colorectal lesions and normal colonic mucosa in a group of Egyptian patients, to our knowledge, this is the first study examined the expression of estrogen receptors by polymerase chain reaction (PCR) and immunohistochemical staining.

\section{PATIENTS AND METHODS}

After being approved by the local scientific \& ethical committee this prospective study was conducted on 45 patients presenting with colonic symptoms, patients selected from those attending to a Gastrointestinal Endoscopy unit in Kasr EL-Aini Hospital, Cairo University from the period of September 2008 to June 2010. Patients were categorized into four groups Group I: Fifteen patients with colorectal cancer, Group II: Ten patients with adenomatous polyps and FAP, Group II: Ten patients with inflammatory bowel diseases, Group IV: Ten patients had an indication for colonoscopy and showed negative full colonoscopic examination, they served as a control subjects.

\subsection{Inclusion Criteria}

Adult patients $>18$ years old indicated for colonoscopic examination for one of the following reasons:

1) Patient with lower GIT symptoms including chronic diarrhea, chronic constipation, alternating bowel habits or bleeding per rectum;

2) Cases with relevant alarming symptoms and signs for CRC e.g. significant unexplained weight loss or un- explained anemia;

3) Patients with remote metastases proved to be adenocarcinoma and were suspected to have CRC;

4) Patients underwent screening for CRC;

5) Patients who have a family or personal history of CRC, genetic CRC syndrome or adenomas;

6) Patients with inflammatory bowel diseases were diagnosed for more than 8 years;

7) Patients known to have FAP, family history of FAP or history of previous adenomatous polyps.

\subsection{Exclusion Criteria}

Patients previously received chemotherapy or hormonal therapy for colorectal malignancy.

Patients who were recently discovered with IBD (less than 8 years duration).

\subsection{Patients Assessment}

After patients written informed consent was approved, all patients were evaluated through their medical history assessment \& detailed clinical examination, laboratory investigations including stool analysis, fecal occult blood testing (FOBT) for those who had no overt blood in stools, complete blood count (CBC) and erythrocyte sedimentation rate (ESR), carcino embryonic antigen (CEA). Radiological investigations were done including abdominal ultrasonograph. Full colonoscopic examination was done by the aid of Pentax colonoscope, model number (EC $3840 \mathrm{~L}$ ) where a biopsy was obtained (Figures 1-3).

\subsection{Tissue Samples (Biopsy Specimens)}

Biopsies were taken from the lesions and the nearby normal colonic mucosa studied patients groups. Biopsies were taken using a standard cold biopsy forceps (CFB2.5-230-S, Wilson Cook medical ${ }^{\mathbb{B}}$ ). In the CRC Group

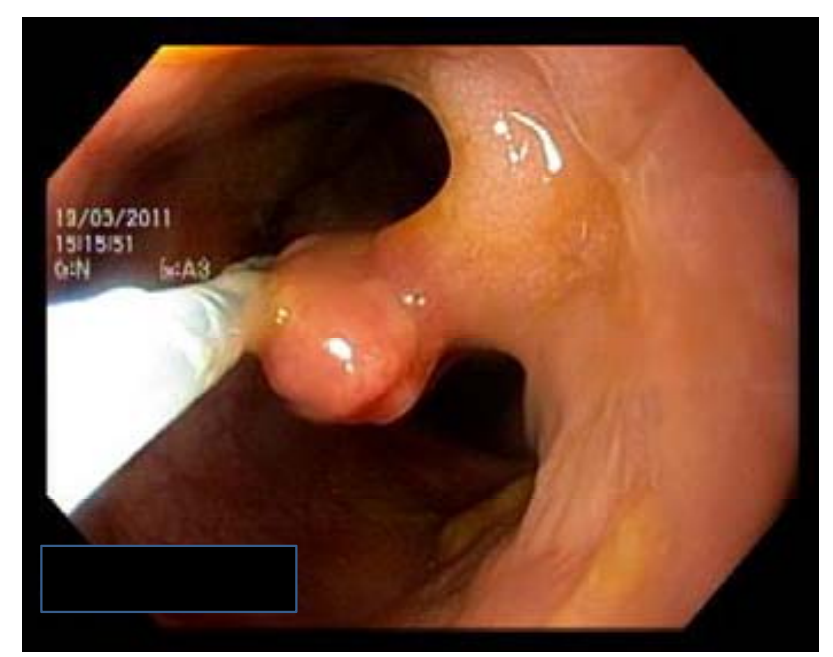

Figure 1. Case of sigmoid adenomtous polyp. 


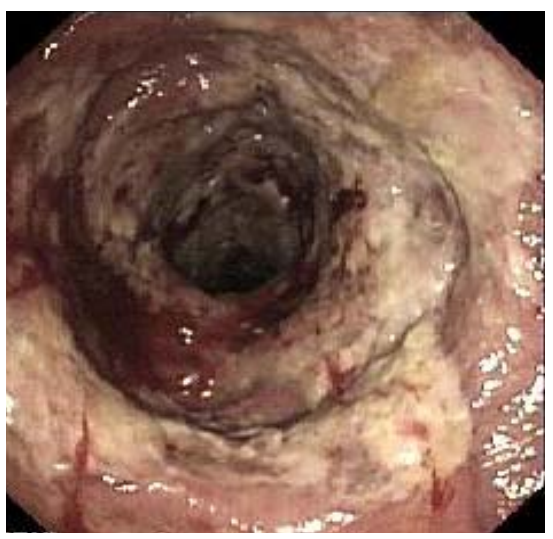

Figure 2. Case of ulcerative colitis with rectal involvement.

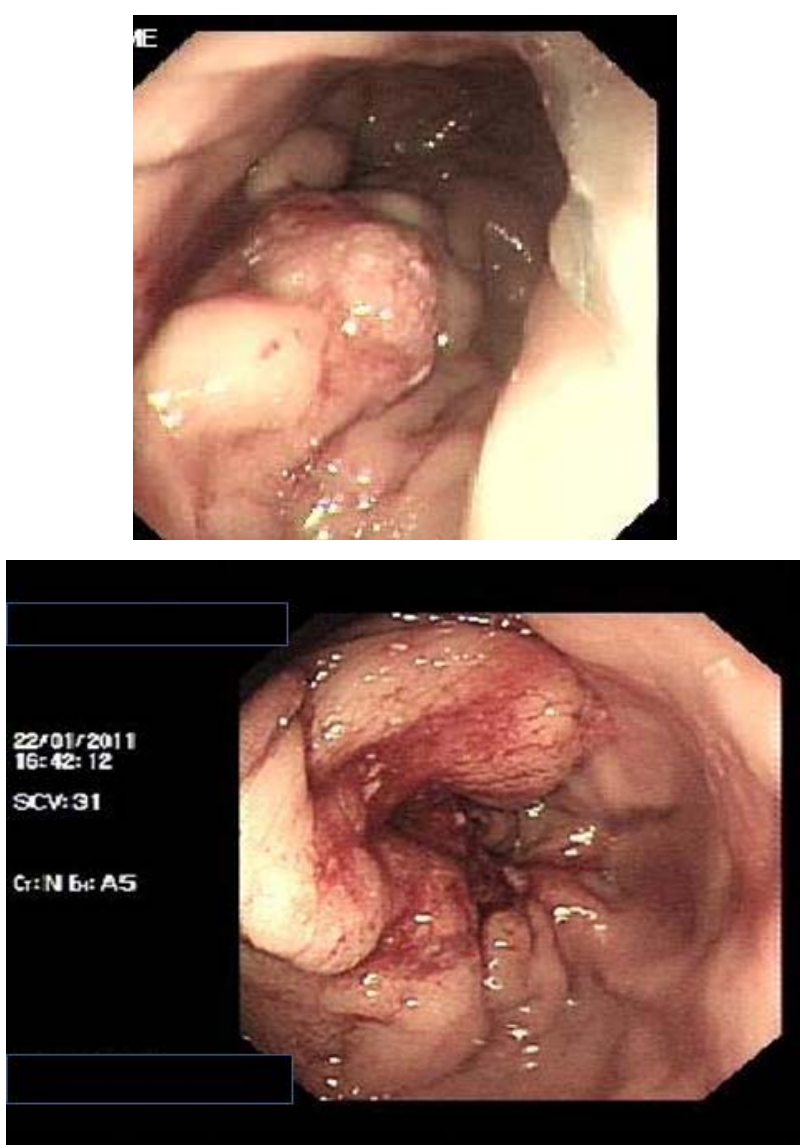

Figure 3. Case of malignant rectal mass.

eight biopsies were taken from the cancer and eight biopsies from the nearby mucosa, in the Polyps Group the Polyps were removed using a polypectomy snare and eight biopsies will be taken from the nearby mucosa, in the IBD Group eight biopsies were taken from the inflamed mucosa and eight biopsies will be taken from the nearby grossly normal colonic mucosa and in the Control Group eight biopsy specimens were taken from the colonic mucosa in all cases.

\section{Samples reservation:}

Biopsy specimens were divided into two parts: One part is used for histopathological diagnosis and immunohistochemical staining for detection of the level $\operatorname{ER} \beta$ \& $\mathrm{ER} \alpha$. The samples are reserved in formalin $10 \%$ till processing, while the second part is used for RT-PCR for quantification of ER $\alpha$ and ER $\beta$ level. The biopsies are preserved in $0.9 \%$ saline and saved promptly after been biopsied in temperature $-20^{\circ} \mathrm{C}$ till samples processing to avoid RNA loss or destruction.

Pathological processing:

Tissue sections were embedded in paraffin and divided into two parts. One part was stained with hematoxylineosin for histopathological diagnosis. The other part was immunostained for detection of estrogen receptors.

\section{Immunohistochemistry:}

$\mathrm{ER} \alpha$ (rabbit monoclonal antibody) and ER-beta (rabbit polyclonal antibody) were purchased from $L A B$ VISION COPORATION, FREMONT CA, USA. Detection Kit (DAB KIT) was also purchased from the same company. Rabbit Monoclonal Antibody recognizes a protein of 67 $\mathrm{kDa}$, which is identified as $\mathrm{ER} \alpha$ and $\mathrm{ER} \beta$ rabbit polyclonal antibody recognizes a protein of $53 \mathrm{kDa}$. ER $\alpha$ and $\mathrm{ER} \beta$ were supplied as pre-diluted antibody which is ready-to-use for immunohistochemical staining for nuclear staining of the tumor. The total number of biopsy specimens was 80 , and the total number of patients was 45. Classification of staining data was executed semiquantitatively by examining the entire tumor present in the tissue sectionusing H-SCORE [16]. The percentage of tumor cells with positive staining (proportion score, $P S$ ) was graded from 0 to 5 points by estimation, where 0 (none), $1(<1 \%), 2(1-<10 \%), 3(10 \%-<33 \%), 4$ (33\% $<66 \%), 5$ (>66\%).

Staining intensity (intensity score, IS) estimated the average staining intensity of positive tumor cells and was scored as: $0=$ negative (no reactivity), $1=$ slight staining (weak), 2 = moderate staining (moderate), 3 = strong staining. In case of heterogeneous staining intensity within the tumor, the most predominant intensity was scored.

H-SCORE: Sum of The PS and IS are added to obtain a total score (range 0-8).

ER $\alpha$ was graded accordingly as follows: (Less than or equal 4) weakly positive score, $(5,6)$ moderately positive, $(7,8)$ strongly positive.

\subsection{RT-PCR Processing}

Tissue sections obtained for RT-PCR quantification were preserved in $0.9 \%$ saline and saved promptly in temperature $-20^{\circ} \mathrm{C}$ until RNA was extracted. The total number of biopsy specimens was 80 , and the total number of patients was 45 .

-RNA tissue extraction: High pure RNA tissue kit 
used for isolation of total RNA from tissue were purchased from ROCHE APPLIED SCIENCE, MANNHEIM, GERMANY. Frozen tissue biopsies are mixed with $400 \mu \mathrm{L}$ of lysis/binding buffer and centrifuged for 2 minutes at maximum speed in microcentrifuge. The collected supernatant are only collected and used in the subsequent steps.

-Reverse transcription (RT): This step is aiming to reverse transcribe RNA (mRNA and total RNA) to cDNA using quantitative RT-PCR on the LightCycler ${ }^{\circledR}$ Carousel-Based System.

-Amplification of cDNA by polymerase chain reaction (PCR): The resulting single-stranded cDNA was amplified in a polymerase chain reaction utilizing the supplied specific designed primers using a LightCycler ${ }^{\circledR}$ TaqMan Master (ROCHE APPLIED SCIENCE, MANNHEIM, GERMANY) on the LightCycler ${ }^{\circledR}$ Carousel-Based System. The specific sense and antisense primers for $\mathrm{ER} \alpha, \mathrm{ER} \beta$ and GAPDH (glyceraldehyde-3-phosphate dehydrogenase) as internal control were based on the previous published articles.

ER $\alpha$ : -sense:

5'-CCTAACTTGCTCTTGGACAGG-3'

-antisense:

5'-CAGCAGCAGGTCATAGAGAGG-3'

$\mathrm{ER} \beta$ : -sense:

5'-GCCAATCATGTGCACCAGTTCCTT-3'

-antisense:

5'-AAAGCCAAGAGAAACGGTGGGCAT-3'

GAPDH: -sense:

5'-TCAACGGCACAGTCAAGGC-3'

-antisense:

5'-AGGGATGATGTTCTGGGCTG-3'

\subsection{ER Detection and Quantification}

LightCycler $^{\circledR}$ TaqMan Master (ROCHE APPLIED SCIENCE, MANNHEIM, GERMANY) on the LightCycler ${ }^{\circledR}$ Carousel-Based System was enabled for high sensitive detection of and quantification of $\operatorname{ER} \alpha$ and $\operatorname{ER} \beta$. The Master Mix (ER $\alpha / E R \beta$ and GADPH) with water PCR grade and the amplified cDNA were placed in a precooled LightCycler ${ }^{\mathbb{B}}$ Capillary and were centrifuged. The capillaries were then transferred to the sample carousel of the LightCycler ${ }^{\circledR}$ instrument. The Degree of ER $\alpha$ and $\mathrm{ER} \beta$ expression were plotted into an automated amplification curve created with LightCycler ${ }^{\circledR}$ Software Version 4.1 for absolute quantification of ER expression. All fluorescence values are normalized to a fluorescence gain. For confirmation of the result, blood samples for patients known to have high expression for both $\operatorname{ER} \alpha$ and $\operatorname{ER} \beta$ were used as control for the tissue samples used in our study to compare our results.

\subsection{Statistical Analysis}

All patients' data were tabulated using Excel XP. Data were processed by SPSS version 12.0 for Windows XP. All qualitative data will be analyzed by Chi-Square test or Fischer's Exact test when appropriate. Chi-square test will be used to calculate the Pearson chi-square and its $\mathrm{P}$ value when both table variables are quantitative.

-The mean and standard deviation: it was used as a suitable statistical parameter to summarize the quantitative data.

-The student $\mathrm{t}$ test: It was used to calculate the difference between numerical data.

-The Pearson chi-square test $\left(\mathrm{X}^{2}\right)$ : was used for studying the difference between studied groups. It is used to statistically test the difference between qualitative data.

-Kappa: Cohen's kappa measures the agreement between the evaluations of two variables when both are rating the same patient. A value of 1 indicates perfect agreement. A value of 0 indicates that agreement is no better than chance.

-Significance of results: the test result was considered non significant if $\mathrm{P}>0.05$, significant difference if $\mathrm{P}<$ 0.05 and highly significant difference if $\mathrm{P}<0.01$.

\section{RESULTS}

The demographic features of the whole studied patients and of each group are summarized in Table 1. Bleeding per rectum was the most common presentation in the studied patients; presenting $64.4 \%$ of the patients (29 patients) and only two patients presented with constipation $(4.4 \%)$. Diarrhea was statistically significant $(\mathrm{P}=$ $0.006)$ in patients of IBD group $(80 \%)$, it was the main presenting symptom, while in the CRC group it present only in $33 \%, 30 \%$ of the control patients and only $10 \%$ of adenomatous polyp group.Types of colonic lesions of the studied patients are demonstrated in Figure 4.

Among the laboratory data; CEA was significantly elevated in CRC group compared with other studied groups (1692 mg/L vs. 4.0, 4.0 and $4.4 \mathrm{mg} / \mathrm{L}$, respectively). Ultrasonographic findings of studied patients showed; metastatic CRC was detected in 3 patients $(20 \%)$; one with multiple hepatic focal lesions diagnosed by biopsy as metastatic adenocarcinoma and the other two patients presented by malignant ascites Colonic thickening was detected in 5 patients $(33.3 \%)$; three at the hepatic flexure and two at the rectosigmoid region. One patient in the adenomatous polyps group showed multiple colonic polypoidal lesions by abdominal ultrasonography. In the IBD group, three of the diagnosed patients with ulcerative colitis showed diffuse thickening of the colonic wall and one Crohn's disease patient showed thickened ileocecal and caecal region by abdominal ultrasonography (Table 2 and Figures 5 and 6). All the studied patients 
Table 1. Demographics, clinical and laboratory data of studied groups.

\begin{tabular}{|c|c|c|c|c|}
\hline \multirow[b]{2}{*}{ Parameter } & \multicolumn{4}{|c|}{ Group } \\
\hline & $\begin{array}{c}\text { CRC group } \\
\mathrm{n}=15\end{array}$ & $\begin{array}{l}\text { Polyp group } \\
\mathrm{n}=10\end{array}$ & $\begin{array}{c}\text { IBD group } \\
\mathrm{n}=10\end{array}$ & $\begin{array}{c}\text { Control group } \\
\mathrm{n}=10\end{array}$ \\
\hline Age (years) & $44.8 \pm ? ?$ & $33.4 \pm ? ?$ & $31 \pm ? ?$ & $44.8 \pm ? ?$ \\
\hline Sex (male/female) & $10 / 5$ & $6 / 4$ & $6 / 4$ & $6 / 4$ \\
\hline $\begin{array}{ll}\text { Clinical presentation: } \\
\text { - } & \text { Diarrhea } \\
\text { - } & \text { Constipation } \\
\text { - } & \text { Bleding per rectum } \\
\text { - } & \text { Mucorrhea } \\
\text { - } & \text { Weight loss } \\
\text { - } & \text { Anemia } \\
\text { - } & \text { Abdominal pain }\end{array}$ & $\begin{array}{c}5(33.3 \%) \\
0(0 \%) \\
8(53.3 \%) \\
1(6.7 \%) \\
11(73.3 \%) \\
6(40 \%) \\
1(6.7 \%)\end{array}$ & $\begin{array}{c}1(10 \%) \\
0 \\
10(100 \%) \\
0 \\
0 \\
4(40 \%) \\
0\end{array}$ & $\begin{array}{c}8(80 \%) \\
0 \\
8(80 \%) \\
7(70 \%) \\
0 \\
4(40 \%) \\
2(20 \%)\end{array}$ & $\begin{array}{c}3(30 \%) \\
2(20 \%) \\
3(30 \%) \\
0 \\
2(20 \%) \\
2(20 \%) \\
6(60 \%)\end{array}$ \\
\hline Hemoglobin (g/dl) & $10.2 \pm 2.2$ & $10.5 \pm 2.5$ & $10.5 \pm 1.8$ & $10.8 \pm 1.9$ \\
\hline TLC $^{\mathbf{a}}$ & $8.5 \pm 2.2$ & $7 \pm 1.5$ & $7 \pm 1.1$ & $8.7 \pm 1.6$ \\
\hline Platelets & $342.5 \pm 121$ & $377 \pm 52$ & $347 \pm 87$ & $290 \pm 67$ \\
\hline $\mathbf{E S R}^{\mathbf{b}}$ & $51 \pm 27$ & $31 \pm 12$ & $49 \pm 27$ & $34 \pm 39$ \\
\hline $\mathbf{C E A}^{\mathrm{c}}$ & $1692 \pm 901$ & $4 \pm 1.5$ & $4.0 \pm 2.3$ & $4.4 \pm 1.7$ \\
\hline
\end{tabular}

${ }^{\mathrm{a}} \mathrm{TLC}$ : total leucocytic count; ${ }^{\mathrm{b} E S R}$ : erythrocyte sedimentation rate; ${ }^{\mathrm{c}} \mathrm{CEA}$ : carcinoemberyonic antigen.

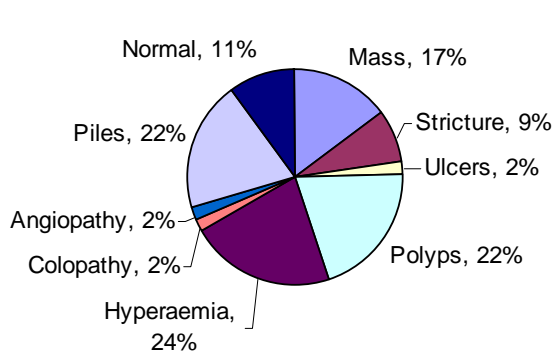

\begin{tabular}{|l|}
\hline$\square$ Mass \\
$\square$ Stricture \\
$\square$ Ulcers \\
$\square$ Polyps \\
$\square$ Hyperaemia \\
$\square$ Colopathy \\
$\square$ Angiopathy \\
$\square$ Piles \\
$\square$ Normal \\
\hline
\end{tabular}

Figure 4. Type of colonic lesions of the studied patients.

showed negative results for estrogen receptors (alpha and beta) the use of immunohistochemical staining (Figure 7) and RT-PCR technique.

\section{DISCUSSION}

The incidence of CRC is increasing globally [1]. It is ranked as the 4 th most common cancer in males and the 2nd for females [17]. It accounts for the third leading cause of cancer-related death in the Western world [4]. In Egypt, CRC ranks the sixth most common cancer in males and the fifth in females. CRC was responsible for $3.9 \%$ of all cancer related mortality and ranking in the seventh cause of cancer death [4].

Estrogen receptors (ER) exist in 2 main forms: $\mathrm{ER} \alpha$ and $\operatorname{ER} \beta$ [5]. $\operatorname{ER} \beta$ is the dominant ER isoform in normal colonic mucosa playing a key role in the mitogenic action of estrogens by providing protection against ER $\alpha$ induced hyper proliferation and the stimulation of apoptosis [6]. $\mathrm{ER} \alpha$ is reported to be minimally expressed in colon cancer cells [18]. ER $\beta$ expression was significantly lower in colon cancer cells than in normal colonic epi- thelium, which paralleled the loss of malignant colon cell dedifferentiation [19].

Alterations in the global methylation of DNA and in specific regulatory genes are two epigenetic alterations found in cancer. However, the significance of pigenetic changes for diagnosis and/or prognosis of colorectal cancer has not been established, although it has been extensively investigated. The profile of global DNA and estrogen receptor (ER)- $\alpha$ gene methylation during cancer development was determined by the analysis of 5-methylcytosine (5-MeC) using immunohistochemical (IHC) staining, dot blot analysis or a quantitative gene methylation assay (QGMA), global DNA hypomethylation and ER- $\alpha$ gene hypermethylation are progressively enhanced from hyperplastic polyps (HPs) $\rightarrow$ adenomatous polyps (APs) $\rightarrow$ adenomatous carcinoma (AdCa). The aberrant methylation can be completely reversed in APs, but not in AdCa by a nonsteroidal anti-inflammatory drug (NSAID) celecoxib, which is a selective inhibitor of cyclooxygenase-2 (Cox-2), suggesting that the epigenetic alterations between colorectal precancer (AP) and cancer (AdCa) are fundamentally different in response to anti-cancer therapy. In normal colorectal mucosa, while global DNA methylation was not affected by aging, ER- $\alpha$ gene methylation was significantly increased with aging. However, this increase did not reach the level observed in colorectal APs. Taken together, reversibility of aberrant global DNA and ER- $\alpha$ gene methylation distinguishes colorectal precancer from cancer.

This prospective study was done on 45 patients presenting with colonic symptoms, attending to Gastrointestinal Endoscopy unit in Kasr EL-Aini Hospital, Cairo 
Table 2. Ultrasonographic features of the studied patients.

\begin{tabular}{|c|c|c|c|c|c|c|c|c|c|c|}
\hline \multirow{3}{*}{ Parameters } & \multicolumn{10}{|c|}{ Group } \\
\hline & \multicolumn{2}{|c|}{ CRC Group } & \multicolumn{2}{|c|}{ Polyps Group } & \multicolumn{2}{|c|}{ IBD Group } & \multicolumn{2}{|c|}{ Control Group } & \multicolumn{2}{|c|}{ Total } \\
\hline & $\mathbf{N}$ & $\%$ & $\mathbf{N}$ & $\%$ & $\mathbf{N}$ & $\%$ & $\mathbf{N}$ & $\%$ & $\mathbf{N}$ & $\%$ \\
\hline Colonic lesions & 5 & 33.3 & 1 & 10 & 4 & 40 & 0 & 0 & 10 & 22.2 \\
\hline Hepatic focal lesions & 1 & 6.7 & 0 & 0 & 0 & 0 & 0 & 0 & 1 & 2.2 \\
\hline Abdominal lymph nodes & 0 & 0 & 0 & 0 & 0 & 0 & 1 & 10 & 1 & 2.2 \\
\hline
\end{tabular}

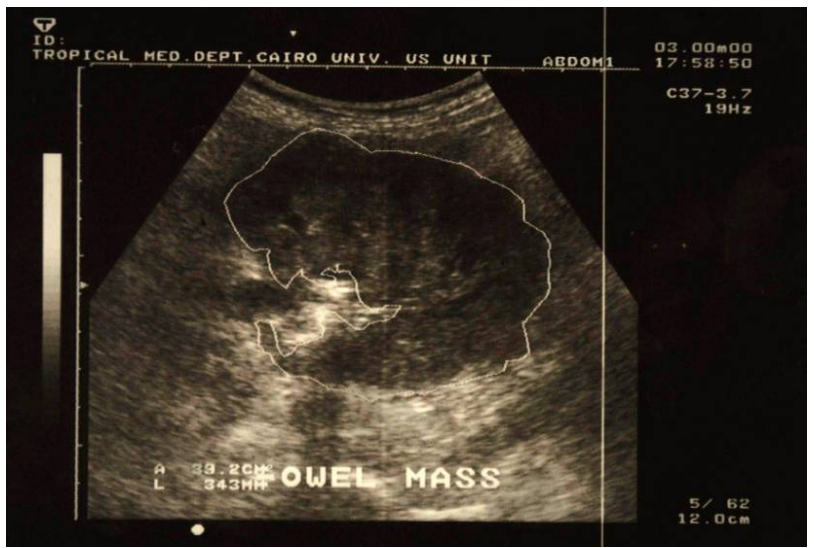

Figure 5. Ultrasonographic appearance of malignant hepatic flexure lesion.

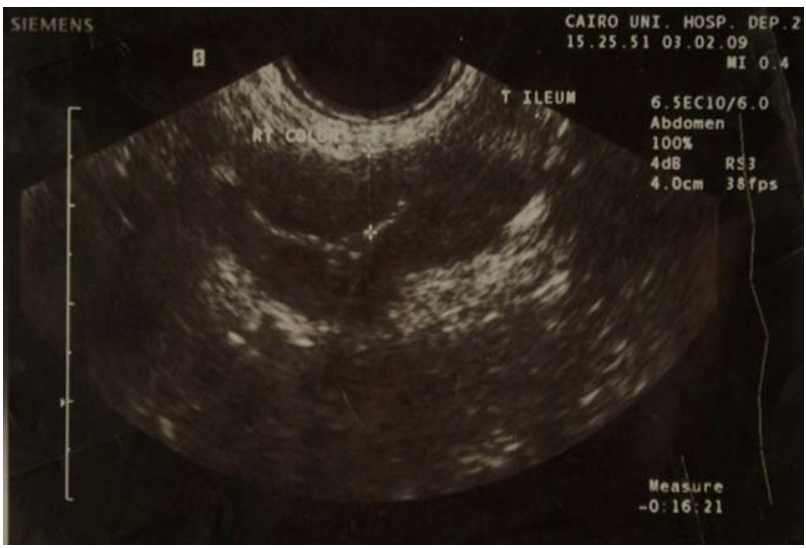

Figure 6. Ultrasonographic appearance of $\mathrm{CD}$ patients with diffuse ileal bowel wall thickening with loss of layering.
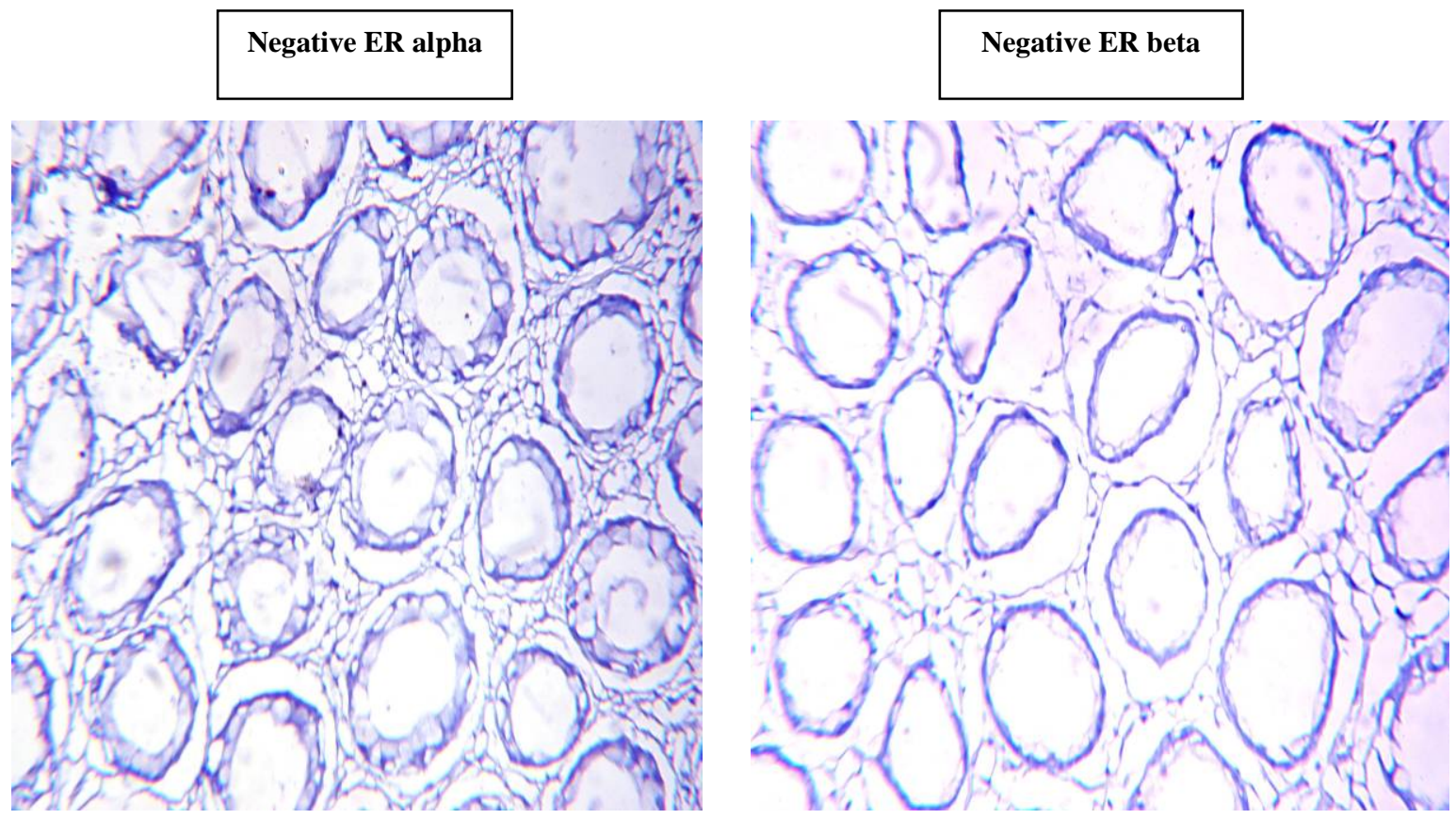

Figure 7. Negative estrogen receptors (alpha \& beta) expression by immunohistochemical staining.

University from the period of September 2008 to June 2010. This study was aiming to assess the expression of estrogen receptors (alpha and beta) in pre-malignant (adenomatous polyps and IBD), malignant colorectal lesions and normal colonic mucosa by immunohisto- chemical staining and RT-PCR. The potential clinical significance of our study is that the expression of estrogen receptors in CRC and normal colonic mucosa may mediate chemopreventive effects for estrogens in the colon and selective ER ligands might be a colon cancer 
prevention strategy. Also, concerning IBD selective ER ligands may be of use in treatment and preventive of recurrence of adenomatous polyps and may improve prognosis in FAP patients and hence decrease development of CRC. The Age incidence of CRC begins to increase significantly between the ages of 40 and 50, and age-specific incidence rates increase in each succeeding decade. In the current study the mean age of the studied patients was 44.8 years old, which agreed with the NCI, 2008, [4] and Ferlay J. et al., 2005 [20] statistical data analysis. Contrary to the El Attar I. 2005 [21] study on the Chinese population, the mean age was 65 years old. This age is lower than the highest age-specific incidence rate in western countries which is $\geq 70$ years in both men and women [22]. This early incidence age may be due to high incidence of infectious colitis in Egypt or genetic predisposition. This finding may enhance the need for early screening for CRC among the Egyptian population based on the early age of cancer development and better genetic studying.

Contrary to a common belief that CRC affects mainly men, Bond J. 2000 [23] and Zakaria MS et al., 2006 [24] stated that CRC almost afflicts men and women almost equally. In our study, males represented $66.6 \%$ of the diagnosed CRC patients in contrary to the study done by Winawer S.J. et al., 2003 [25] in which males to females ratio was $1: 1$. This may be to the larger sample size used in their study (including 159 patients). However, 75\% of the rectal cancer was men, which are in agreed with the WHO, 2006, [2] cancer statistics. The specific reasons for that predominance of rectal cancer are presently unclear [1].

CRC may be suspected from one or more of presentation or may be asymptomatic and discovered by routine screening of average and high risk subjects [26]. The main indications for colonoscopy in our patients were weight loss $(73.3 \%)$ followed by bleeding per rectum $(53.3 \%)$ and anaemia (40\%). The prognosis of CRC depends on the histological pattern of CRC and the malignnant spread. Advanced metastatic adenocarcinoma was detected in $20 \%$ of our patients coinciding with the same percentage found in the USA cancer statistics done by Jemal, A. et al., 2009 [1] that approximately $20 \%$ of patients have distant metastatic disease at the time of presentation. Concerning the histopathological examination of the patients; all cases were diagnosed as adenocarcinoma with $20 \%$ showed mucinous adenocarcinoma with high grade dysplasia. Our results are in accordance with the results of Kanazawa, T. et al. 2002 [27] and Slattery, M.L. et al., 2000 [28].

In our study, detection of the estrogen receptors (ER $\alpha$ and $\operatorname{ER} \beta$ ) in the CRC patients and pairing normal appearing mucosa were negative by both immunohistochemical staining and RT-PCR technique. This result was similar to that found by the two studies done by [29,30].

Concerning $\mathrm{ER} \alpha$, our results coincide with that of Foley EF et al. 2000 [31] who studied ER $\alpha$ in CRC and near by tissue in 29 cases by three different techniques (ligand binding assay, quantitative enzyme immunoassay, and immunohistochemistry). All cases examined with the quantitative enzyme immunoassay \& the immunohistological technique were estrogen receptor negative. Also Qiu Y. et al. 2002 [32], Konstantinopoulos, P.A. et al. 2003 [18] and Wada-Hiraike, O. et al. 2006 [33] come in agreement with our results that in normal human colon tissue samples and in CRC of the adenocarcinoma type $\mathrm{ER} \alpha$ was minimally expressed by immunohistochemical staining.

On the other hand, our results were contradictory to El Attar I. et al. 2005 [21] who studied 12 Chinese patients with CRC and their paired normal colonic mucosa using immunohistochemical staining and RT-PCR and showed ER $\alpha$ mRNA expressed in $25 \%$ of cases with CRC and $16.6 \%$ of the normal colonic mucosa. This contradictory may be resulted from different racial and genetic background.

In previous study done by the current research team showed positive ER $\alpha$ expression immunohistochemistry staining in only $4.7 \%$ of cases and it was weakly positive (Seif, et al., 2006), detection of ER by RT-PCR is more sensitive and reliable.

Concerning our results about negative expression of $\mathrm{ER} \beta$ in $\mathrm{CRC}$ and the near by normal colonic mucosa; our result is similar to that found by Qiu, Y. et al. 2002 [32] and Witte, D. et al. 2001 [34] that the expression of $\operatorname{ER} \beta$ is selectively lost in CRC. Contrary to our results, El Attar, I. et al. 2005 [21] ER $\beta$ mRNA was expressed in 83.3\% CRC tissue and 91.7\% paired normal colon tissue. This contradictory may be due to racial variant or the sample size used (in our study 15 patients only were studied, while 40 patients in their study).

However Xie, L.Q. et al. 2004 [19], Konstantinopoulos, P.A. et al. 2003 [18] and Galluzzo, P. et al. 2007 [35] showed that $\operatorname{ER} \beta$ expression was significantly lower in colon cancer cells than in the normal colonic epithelium, and that there was a progressive decline in ER $\beta$ expression, which paralleled the loss of malignant colon cell differentiation.

$\mathrm{ER} \alpha$ and $\operatorname{ER} \beta$ in adenomatous polyps and the near-by grossly normal colonic mucosa were evaluated by immunohistochemistry and RT-PCR. ER $\alpha$ and ER $\beta$ were negative in all adenomatous polyps and the normal colonic tissues. Few studies have been conducted, and with conflicting results, on the possible protective effect of estrogens against the development of adenomatous polyps in the colon [36]. Contrary to the study done by Di Leo, A. et al. 2008 [37] studied adenomatous polyps in 
30 patients. Measurement of ER was performed in the cytosol and in the nuclei of the polyps. ER receptors were positive in $30 \%$ of the cytosol of the adenomatous polyps. This contradictory to our results may be related to that we detect the ER in the nuclei and not the cytosol, being more important.

In accordance to our results, Zakaria, M.S. et al. 2007 [38] evaluated ER $\beta$ expression in adenomatous polyps in 25 patients and its possible correlation with proliferative activity and apoptosis. There was a significant reduction of ER $\beta$ expression and significantly increased in cell proliferative activity.

$\mathrm{ER} \alpha$ and $\mathrm{ER} \beta$ in the inflamed and ulcerated mucosa of IBD patients and the near-by grossly looking normal colonic mucosa was evaluated by immunohistochemistry and RT-PCR. Both receptors were negative in all the inflamed tissue and all the normal nearby tissues. This is possibly because either they are absent from the start or due to the absence of dysplasia in our cases. The reported studies were using ER $\beta$ ligands and their effect in improving inflammation in experimental animal with IBD and not the expression of the receptors. The only available study was done by Rulong Shen et al. 2009 [39] to detect ER $\alpha$ by immunohistochemistry and it was absent in all specimens and with similar results to our study.

To conclude, our study was designed to evaluate the expression of $\mathrm{ER} \alpha$ and $\mathrm{ER} \beta$ in $\mathrm{CRC}$, adenomatous polyps, IBD and normal colonic mucosa were negative in all the studied cases by both techniques. The number of studies in the literature was little in comparison with our results and even most of the studies showed either the expression of only one type of ER or use only one technique (e.g. immunohisochemical staining), while our study used two techniques, with PCR as a confirmatory method which made the role of estrogen receptors in colonic mucosa, precancerous and colorectal cancer is doubtful, at least among our patients. The contradictory may be raised due to racial and so genetic difference in the population studied.

\section{REFERENCES}

[1] Jemal, A., Siegel, R., Ward, E., Hao, Y., Xu, J. and Thun, M.J. (2009) Cancer statistics. CA: A Cancer Journal for Clinicians, 59, 225-249.

[2] World Health Organization (2006) Cancer. Fact Sheet (No. 297), Geneva.

http://www.who.int/mediacentre/factsheets/fs297/en/print. $\underline{\mathrm{html}}$

[3] National Cancer Institute (2002) Administrative and statistical report for NCI, 2002-2008. www.nci.edu.eg

[4] National Cancer Institute (2008) Administrative and statistical report for NCI. http://www.nci.edu.eg

[5] Leung, Y.K., Mak, P., Hassan, S., et al. (2006) Estrogen receptor (ER)- $\beta$ isoforms: A key to understanding ER- $\beta$ signaling. Proceedings of the National Academy of Sciences of the United States of America, 103, 13162-13167. doi: $10.1073 /$ pnas.0605676103

[6] Campbell-Thompson, M., Lynch, I. and Bhardwaj, B. (2001) Expression of estrogen receptor (ER) subtypes and ERbeta isoforms in colon cancer. Cancer Research, 61, 632-640.

[7] Mueller, S.O. and Korach, K.S. (2001) Estrogen receptors and endocrine diseases: Lessons from estrogen receptor knockout mice. Current Opinion in Pharmacology, 1, 613-619.

[8] Björnström, L. and Sjöberg, M. (2005) Mechanisms of estrogen receptor signaling: Convergence of genomic and nongenomic actions on target genes. Molecular Endocrinology, 19, 833-842.

[9] Konstantinopoulos, P.A., Kominea, A., Vandoros, G., et al. (2003) Oestrogen receptor $\beta(\mathrm{ER} \beta)$ is abundantly expressed in normal colonic mucosa, but declines in colon adenocarcinoma paralleling the tumour's dedifferentiation. European Journal of Cancer, 39, 1251-1258. doi:10.1016/S0959-8049(03)00239-9

[10] Harnish, D., Albert, L., Leathurby, Y. et al. (2004) Beneficial effects of estrogen treatment in the HLA-B27 transgenic rat model of inflammatory bowel disease. American Journal of Physiology Gastrointestinal and Liver Physiology, 286, 118-125. doi:10.1152/ajpgi.00024.2003

[11] Gustfsson, J.- $\AA$. (2006) ER $\beta$ scientific visions translate to clinical uses. Climacteric, 9, 156-160. doi: $10.1080 / 14689360600734328$

[12] Harris, H.A. (2007) Estrogen receptor- $\beta$ : Recent lessons from in vivo studies. Molecular Endocrinology, 21, 1-13. doi:10.1210/me.2005-0459

[13] Galluzzo, P., Caiazza, F., Moreno, S., et al. (2007) Role of ERbeta palmitoylation in the inhibition of human colon cancer cell proliferation. Endocrine-Related Cancer, 14, 153-167. doi:10.1677/ERC-06-0020

[14] Di Leo, A., Barone, M., Maiorano, E., et al. (2008) ERbeta expression in large bowel adenomas: Implications in colon carcinogenesis. Digestive and Liver Disease, 40, 260-266. doi:10.1016/j.dld.2007.10.018

[15] Fletcher, R.H. (2000) Screening for colorectal cancer: Strategies in patients at average risk. http://www.uptodate.com/contents/screening-for-colorect al-cancer-strategies-in-patients-at-average-risk

[16] National Cancer Institute (2009) Cancer. http://www.cancer.gov/cancertopics/commoncancers

[17] Campbell-Thompson, M., Lynch, I. and Bhardwaj, B. (2001) Expression of estrogen receptor (ER) subtypes and ERbeta isoforms in colon cancer. Cancer Research, 61, 632-640.

[18] Konstantinopoulos, P.A., Kominea, A., Vandoros, G., et al. (2003) Oestrogen receptor $\beta(\mathrm{ER} \beta)$ is abundantly expressed in normal colonic mucosa, but declines in colon adenocarcinoma paralleling the tumour's dedifferentiation. European Journal of Cancer, 39, 1251-1258. doi:10.1016/S0959-8049(03)00239-9

[19] Xie, L.Q., Yu, J.P. and Luo, H.S. (2004) Expression of estrogen receptor $\beta$ in human colorectal cancer. World 
Journal of Gastroenterology, 10, 214-217.

[20] Ferlay, J., Bray, F., Pisani, P., et al. (2005) Cancer incidence, mortality and prevalence worldwide. CA: A Cancer Journal for Clinicians, 55, 74-108.

[21] El Attar, I. (2005) Colo-rectal cancer: Magnitude of the problem. Annual cancer. Conference of the Egyptian Cancer Society, Danish Cancer Society \& Aarhus University Hospital, Cairo, 9-11 February.

[22] Mc Leod, H. and Murray, G. (1999) Tumor markers of prognosis in colorectal cancer. British Journal of Cancer, 79, 191-203. doi:10.1038/sj.bjc.6690033

[23] Bond, J. (2000) Colorectal cancer update. Prevention, screening, treatment, and surveillance for high risk groups. Medical Clinics of North America, 84, 1163-1182. doi:10.1016/S0025-7125(05)70281-9

[24] Zakaria, M.S., Hashem, A., Abdelbary, M.S., et al. (2006) The pattern of colonic diseases in Egypt: A colonoscopic study. Arab Journal of Gastroenterology, 7, 53-58.

[25] Winawer, S.J., Fletcher, R., Rex, D., et al. (2003) Colorectal cancer screening and surveillance: Clinical guidelines and rationale-Update based on new evidence. Gastroenterology, 124, 544. doi:10.1053/gast.2003.50044

[26] Deans, G.T., Patterson, C.C., Parks, T.G., et al. (1994) Colorectal carcinoma: Importance of clinical and pathological factors in survival. Annals of the Royal College of Surgeons of England, 76, 59-64.

[27] Kanazawa, T., Watanabe, T., Kazama, S., et al. (2002) Poorly differentiated adenocarcinoma and mucinous carcinoma of the colon and rectum show higher rates of loss of heterozygosity and loss of E-cadherin expression due to methylation of promoter region. International Journal of Cancer, 102, 225-229. doi:10.1002/ijc.10690

[28] Slattery, M.L., Samowitz, W.S. and Holden, J.A. (2000) Estrogen and progesterone receptors in colon tumors. American Journal of Clinical Pathology, 113, 364-368. doi:10.1309/5MHB-K6XX-QV50-PCJQ

[29] Ekem, T.E., Bahadir, B., Gun, B.D., et al. (2008) Colorectal carcinomas: Clinicopathologic investigation, correlation with expression of estrogen and progesterone receptors. Turkish Journal of Cancer, 38, 118-122.

[30] Dawson, P., Shousha, S., Blair, S., et al. (1990) Oestro- gen receptors in colorectal carcinoma. Journal of Clinical Pathology, 43, 149-151. doi:10.1136/jcp.43.2.149

[31] Foley, E.F., Jazaeri, A.A., Shupnik, M.A., et al. (2000) Selective loss of estrogen receptor $\beta$ in malignant human colon. Cancer Research, 60, 245-248.

[32] Qiu, Y., Waters, C., Lewis, A., et al. (2002) Oestrogeninduced apoptosis in colonocytes expressing oestrogen receptor beta. Journal of Endocrinology, 174, 369-377. doi:10.1677/joe. 0.1740369

[33] Wada-Hiraike, O., Imamov, O., Hiraike, H., et al. (2006) Role of estrogen receptor $\beta$ in colonic epithelium. Proceedings of the National Academy of Sciences of the United States of America, 103, 2959-2964. doi:10.1073/pnas.0511271103

[34] Witte, D., Chirala, M., Younes, A., et al. (2001) Estrogen receptor beta is expressed in human colorectal adenocarcinoma. Human Pathology, 32, 940-944. doi:10.1053/hupa.2001.27117

[35] Galluzzo, P., Caiazza, F., Moreno, S., et al. (2007) Role of ERbeta palmitoylation in the inhibition of human colon cancer cell proliferation. Endocrine-Related Cancer, 14, 153-167. doi:10.1677/ERC-06-0020

[36] Concolino, G., Arrabito, G., Buonomo, O., et al. (1986) Nuclear steroid receptors and dysplasia in adenomatous polyps of the colon as markers of high risk for malignant transformation. Cancer Detection and Prevention Journal, 9, 477-484.

[37] Di Leo, A., Barone, M., Maiorano, E., et al. (2008) ERbeta expression in large bowel adenomas: Implications in colon carcinogenesis. Digestive and Liver Disease, 40, 260-266. doi:10.1016/j.dld.2007.10.018

[38] Zakaria, M.S., Abdel-Bary, M.S., Said, M., Yosry, Ay., Seif, M. and Hindawy A. (2007) Evaluation of estrogen receptors in malignant and premalignant colorectal lesions. Egyptian journal of Medical Sciences, 28, 12.

[39] Shen, R.L., Tao, L.H., Xu, Y.Q., Chang, S., Van Brocklyn, J. and Gao, J.-X. (2009) Reversibility of aberrant global DNA and estrogen receptor- $\alpha$ gene methylation distinguishes colorectal precancer from cancer. International Journal of Clinical and Experimental Pathology, 2, 21-33. 